\title{
An Observation of Winter Breeding by Two Anurans from Bangladesh
}

Faysal Ahmad and Shayer Mahmood Ibney Alam

Department of Zoology, Jagannath University, Dhaka 1100, Bangladesh (faysal.nature@gmail.com)

Photographs by the senior author.

mphibians are ectotherms that reduce activity in extreme Atemperatures, and many hibernate during the winter or become inactive when conditions are unfavorable. Little is known about the range of temperatures that amphibians can tolerate and maintain reproductive activity (Storey and Storey 1986). In Bangladesh, the climate is sub-tropical, with a brief winter that generally begins in November and continues until February, peaking from mid-December to mid-January. Data documenting breeding temperatures and egg types of any amphibian species from Bangladesh are lacking.

Near Barlekha in Maulvibazar District $\left(24^{\circ} 38^{\prime} 21^{\prime \prime} \mathrm{N}\right.$ $\left.92^{\circ} 13^{\prime} 16^{\prime \prime} \mathrm{E}\right)$ on 16 December 2012 at $1240 \mathrm{~h}$, we observed amplexus in two species of amphibians, the Red Narrowmouthed Frog (Microhyla rubra; Fig. 1) and the Asian Common Toad (Duttaphrynus melanostictus, Fig. 2). The first author found the small pool of clear water by tracking the

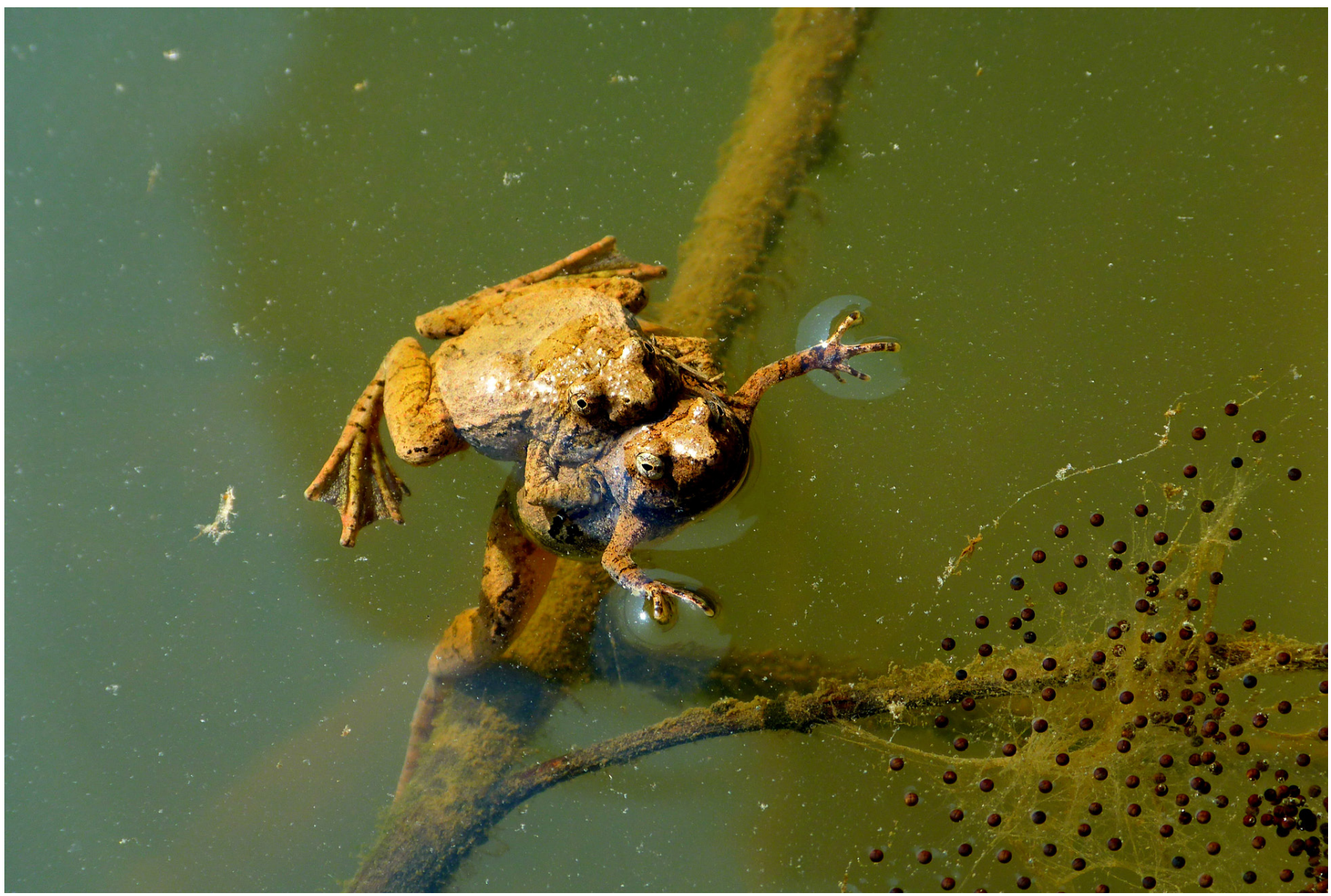

Fig. 1. Red Narrow-mouthed Frogs (Microhyla rubra) in amplexus with a raft of clustered eggs in the foreground. 


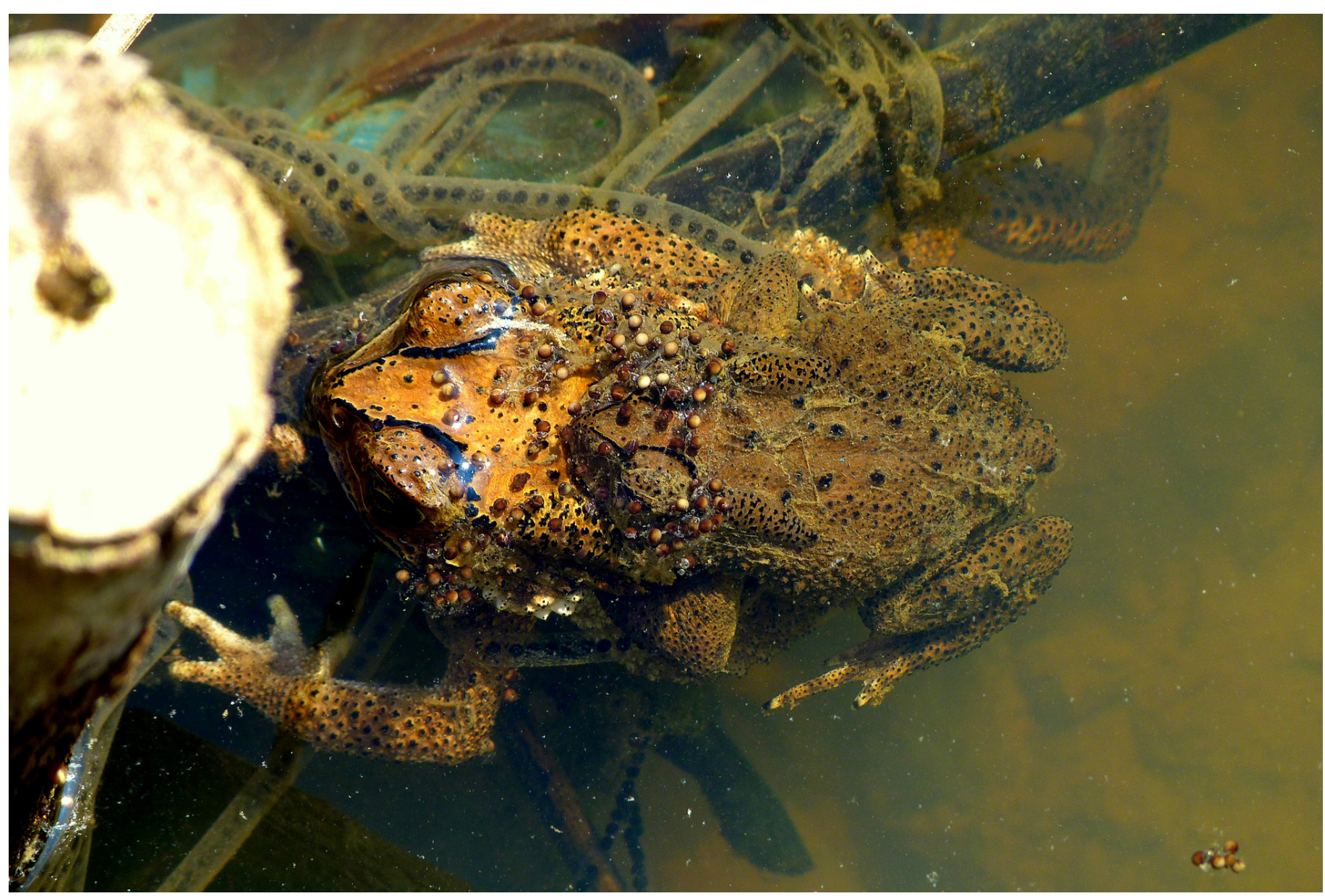

Fig. 2. Asian Common Toads (Duttaphrynus melanostictus) in amplexus with strings of eggs attributable to this species (note that single eggs in the vicinity of the toads are those of the Red Narrow-mouthed Frog.

breeding calls of $M$. rubra. Due to the dry winter season, the flow of water was reduced in a channel of the Madhabkunda Waterfall, leaving a number of small pools along the main channel. The water in the pool was shallow $(-7.5-120 \mathrm{~cm})$ and surrounded by bushes. Water temperature was $9{ }^{\circ} \mathrm{C}$.

Microhyla rubra (Mycrohylidae) has a wide distribution at lower elevation across Bangladesh and peninsular India to Sri Lanka, rarely occurring above $500 \mathrm{~m}$ asl (Kirtisinghe 1957; Padhye et al. 2004; Manamendra-Arachchi and Pethiyagoda 2006). The natural history and reproductive biology of many microhylid frogs are poorly known, and small body size, nocturnal habits, and cryptic coloration might be largely responsible (e.g., Wassersug 1980; Donnelly et al. 1990; Lehr et al. 2007). Red Narrow-mouthed Frogs are most frequently encountered in moist situations under logs, piles of rubble, haystacks, and stones, and egg deposition occurs primarily in ephemeral pools in Sri Lanka (Bowatte and Meegaskumbura 2011).

Duttaphrynus melanostictus (Bufonidae) occurs from Pakistan to the Malay Peninsula. It has been recorded from sea level to $1,800 \mathrm{~m}$ asl and is most frequently found in dis- turbed lowland habitats, from upper beaches and riverbanks to human-dominated agricultural and urban areas (Mathew 1999; Van Dijk et al. 2004). Asian Common Toads breed in still and slow-flowing rivers and temporary and permanent ponds and pools (Van Dijk et al. 2004). Breeding depends on rainfall and temperature. In areas with seasonal monsoon rains, breeding often peaks at the start of the wet season; where climate is more stable, breeding can occur throughout the year (Jørgensen et al. 1986; Mathew 1999).

We observed 21 Red Narrow-mouthed Frogs and seven Asian Common Toads in the pool. We also found clustered egg clutches attributable to M. rubra (Fig. 1) and long strings of eggs laid by D. melanostictus (Fig. 2). No published records document winter inactivity or breeding of $M$. rubra in Bangladesh. However, D. melanostictus has been observed seeking shelter and becoming inactive during the winter in some areas of Bangladesh (pers. obs.). Consequently, breeding during the winter dry season might be a local adaptation attributable to the availability of water and not necessarily applicable to most populations of either species in Bangladesh. 


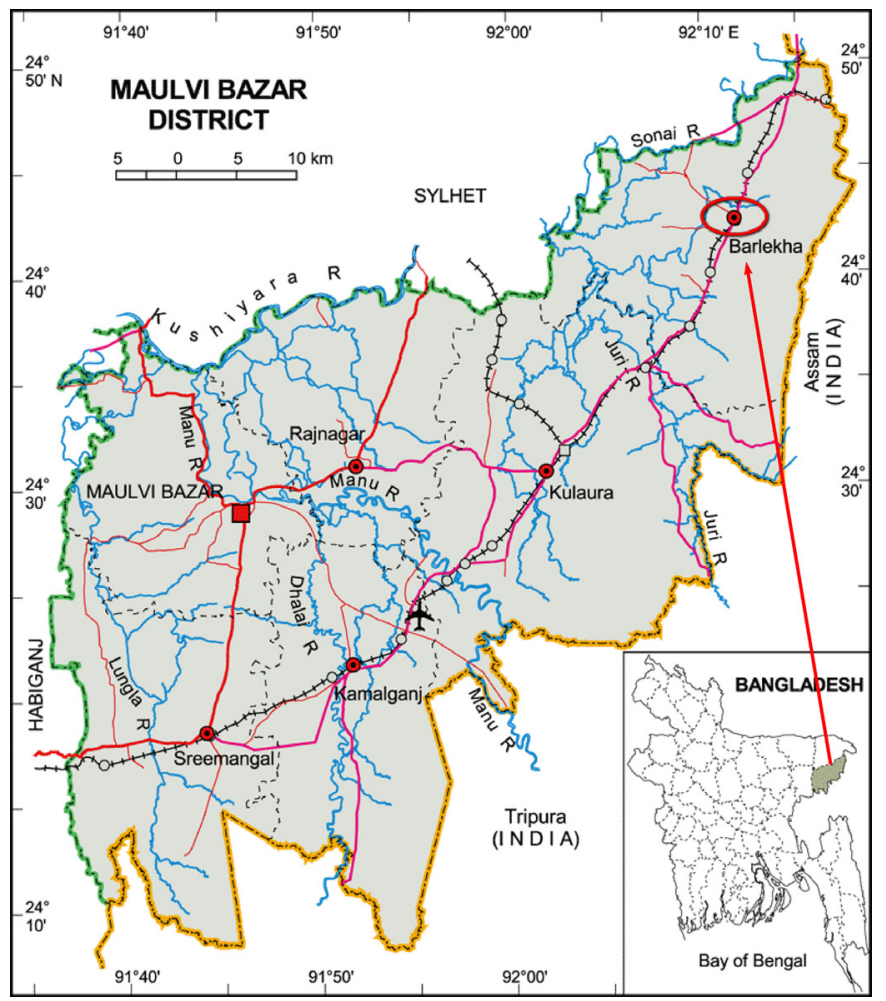

Fig. 3. Map of Maulvibazar District (Bangladesh) showing the approximate location of the site near Barlekha where two species of anurans were breeding in December 2012.

\section{Acknowledgements}

The authors are grateful to the Nature Study and Conservation Club of the Department of Zoology, Jagannath University, Dhaka 1100. Kathleen Ninneman and Hector Hinojosa pro- vided moral support and Stephen Mahony and Christopher E. Smith provided important information.

\section{Literature Cited}

Bowatte, G. and M. Meegaskumbura. 2011. Morphology and ecology of Microhyla rubra (Anura: Microhylidae) tadpoles from Sri Lanka. Amphibian and Reptile Conservation 5:22-32.

Donnelly, M.A., R.O. de Sa, and C. Guyer. 1990. Description of the tadpoles of Gastrophryne pictiventris and Nelsonophryne aterrima (Anura: Microhylidae), with a review of morphological variation in free-swimming microhylid larvae. American Museum Novitates 2976:1-19.

Jørgensen, C.B., K. Shakuntala, and S. Vijayakumar. 1986. Body size, reproduction and growth in a tropical toad, Bufo melanostictus, with a comparison of ovarian cycles in tropical and temperate zone anurans. Oikos 46:379-389.

Kirtisinghe, P. 1957. The Amphibia of Ceylon. Privately published by the author, Colombo, Sri Lanka.

Lehr, E., L. Trueb, P.J. Venegas, and E. Arbeláez. 2007. Descriptions of the tadpoles of two Neotropical microhylid frogs, Melanophryne carpish and Nelsonophryne aequatorialis (Anura: Microhylidae). Journal of Herpetology 41:581-589

Manamendra-Arachchi, K. and R. Pethiyagoda. 2006. Amphibians of Sri Lanka. Wildlife Heritage Trust, Colombo, Sri Lanka.

Mathew, M. 1999. Studies on some Aspects of the Biology and Ecology of Common Indian Toad Bufo melanostictus Schneider (Class Amphibia; Order Anura). Unpublished Ph.D. Thesis, Mahatma Ghandi University, Kottayam, Kerala, India (www.mgutheses.org/page/?q=T\%20 0581\&search $=\&$ page $=\& \mathrm{rad}=\% 23184$ ).

Padhye, A., A. de Silva, S. Dutta, T. Kumar Shrestha, K. Manamendra-Arachchi, and S. Bordoloi. 2004. Microhyla rubra. IUCN Red List of Threatened Species. Version 2014.3 (www.iucnredlist.org).

Storey, K.B. and J.M. Storey. 1986. Freeze tolerance and intolerance as strategies of winter survival in terrestrially-hibernating amphibians. Comparative Biochemistry and Physiology Part A: Physiology 83:613-617.

Van Dijk, P.P., D. Iskandar, M. Wai Neng Lau, G. Huiqing, G. Baorong, L. Kuangyang, C. Wenhao, Y. Zhigang, B. Chan, S. Dutta, R. Inger, K. Manamendra-Arachchi, and M. Sharif Khan. 2004. Duttaphrynus melanostictus. IUCN Red List of Threatened Species. Version 2014.3 (www.iucnredlist.org).

Wassersug, R.J. 1980. Internal oral features of larvae from eight anuran families: Functional, systematic, evolutionary and ecological considerations. Publications of the Museum of Natural History, University of Kansas 68:1-146. 